\title{
Buffalo Milk as a Source of Probiotic Functional Products
}

\author{
Márcio Vargas-Ramella ${ }^{1,2} \mathbb{D}$, Mirian Pateiro ${ }^{2} \mathbb{D}$, Aristide Maggiolino ${ }^{3} \mathbb{D}$, Michele Faccia ${ }^{4} \mathbb{D}$, Daniel Franco $^{2} \mathbb{D}$, \\ Pasquale De Palo ${ }^{3}$ and José M. Lorenzo ${ }^{2,5, * \mathbb{D}}$
}

1 Centro de Educação Superior da Região Sul—CERES da Universidade do Estado de Santa Catarina_UDESC, Laguna 88790-000, Brazil; marcio.ramella@hotmail.com

2 Centro Tecnológico de la Carne de Galicia, Rúa Galicia No. 4, Parque Tecnológico de Galicia, San Cibrao das Viñas, 32900 Ourense, Spain; mirianpateiro@ceteca.net (M.P.); danielfranco@ceteca.net (D.F.)

3 Department of Veterinary Medicine, University of Bari A. Moro, Valenzano, 70010 Bari, Italy; aristide.maggiolino@uniba.it (A.M.); pasquale.depalo@uniba.it (P.D.P.)

4 Department of Soil, Plant and Food Sciences, University of Bari, Via Amendola 165/A, 70126 Bari, Italy; michele.faccia@uniba.it

5 Área de Tecnología de los Alimentos, Facultad de Ciencias de Ourense, Universidad de Vigo, 32004 Ourense, Spain

* Correspondence: jmlorenzo@ceteca.net

check for updates

Citation: Vargas-Ramella, M.; Pateiro, M.; Maggiolino, A.; Faccia, M.; Franco, D.; De Palo, P.; Lorenzo, J.M. Buffalo Milk as a Source of Probiotic Functional Products. Microorganisms 2021, 9, 2303. https://doi.org/10.3390/ microorganisms 9112303

Academic Editors: Pascal Bonnarme and Christophe Chassard

Received: 23 September 2021

Accepted: 3 November 2021

Published: 5 November 2021

Publisher's Note: MDPI stays neutral with regard to jurisdictional claims in published maps and institutional affiliations.

Copyright: (c) 2021 by the authors. Licensee MDPI, Basel, Switzerland. This article is an open access article distributed under the terms and conditions of the Creative Commons Attribution (CC BY) license (https:/ / creativecommons.org/licenses/by/ $4.0 /)$.

\begin{abstract}
In the past two decades, consumption of food has been accruing due to its health claims which include gastrointestinal health, improved immunity, and well-being. Currently, the dairy industry is the sector where probiotics are most widely used, especially in fermented milk, cheese, yoghurt, butter, and dairy beverages. Although, it is still necessary to face many challenges regarding their stability and functionality in food. Considering the increasing demand for healthy products, it is necessary to develop strategies that aim to increase the consumption of functional foods in order to meet probiotic usefulness criteria and the consumer market. This review aimed to promote the utilization of buffalo milk considering its probiotic effects as a functional food and natural remedy to various ailments, emphasizing the potential of innovation and the importance of milk-based products as health promoters. The intake of probiotics plays an important role in modulating the health of the host, as a result of a balanced intestinal microbiota, reducing the risk of development of various diseases such as cancer, colitis, lactose intolerance, heart diseases, and obesity, among other disorders. However, further studies should be carried out to deepen the knowledge on the relationship between raw buffalo milk, its dairy products microbiota and consumer's health beneficial effects, as well as to implement a strategy to increase the variety and availability of its products as a functional food in the market.
\end{abstract}

Keywords: functional foods; healthy dairy products; intestinal microbiota lactic acid bacteria; mozzarella

\section{Introduction}

Domesticated buffaloes (Bubalus bubalis) are highly adaptable and multipurpose animals [1]. Buffalo rearing has been facilitated for its versatility, efficient use of low-quality and high-fiber diets [2], parasite resistance, good quality meat, and rich milk and milk products [3]. In some countries, buffaloes have a social and cultural importance, providing draught power and an affordable source of meat and milk $[4,5]$.

World milk production has almost doubled in the last twenty years, highlighting buffalo milk with an annual growth rate higher $(\sim 2.5 \%)$ than that presented by cow's milk [6]. During this time, the breeds for milk production have been selected and notably improved [3]. The largest buffalo milk producers are India, Pakistan, and China, while the higher producer in Europe is Italy, ranked at the 6th position in the worldwide context [7]. Although, it is also produced in countries such as Bulgaria, Germany, or Greece [8]. Moreover, in 2019, buffalo milk was ranked at second after cow milk, representing $15 \%$ of the total worldwide milk production ( 910 million tons) [6]. Fresh buffalo milk accounts for 
over $50 \%$ of drinking milk in India, Pakistan, Egypt, and Nepal. In addition, buffalo dairy products are traditional from Asian and Caucasian countries [9], in which dairy foods such as dahi, ghee, and yoghurt are very consumed. Despite the fact that it is not common in Europe, this type of milk has an important market in some Mediterranean countries, and the dairy buffalo industry is thriving on the gained popularity of mozzarella cheese [4,9-11]. In addition, the nutritional benefits of buffalo milk make it a potential substitute for cow's milk, associated with significant milk allergies [12]. In this regard, some varieties of cheese that were made from cow's milk are now made from buffalo's milk [13]. This emerging global market offers a huge boost for the buffalo milk industry [14].

Milk is considered a very important source of nutrients due to the beneficial effects of many bioactive compounds present in its composition [4]. In line with this, buffalo milk presents specific properties and health-promoting characteristics for consumers, compared with other species $[4,11]$. The flavour, taste, and texture of buffalo milk products can be influenced by the microbial flora present in raw milk, as well as potential to contribute to health through the probiotic-associated traits [11]. Health-promoting bacteria isolated from milk and its products are commonly referred to as "probiotics". According to the latest definition of the International Scientific Association for Probiotics and Prebiotics (ISAPP), probiotics are "live microorganisms that, when administered in adequate amounts, confer a health benefit on the host" [15]. In the last five years, the popularity of probiotics boosted substantially, and there are many experimental and clinical pieces of evidence that demonstrate their benefits for health [16]. The prevention and treatment of diseases, as well as health "optimization", are among their biological effects [16]. In addition to dairy products, they can be consumed as raw vegetables and fruits or fermented pickles [17].

Functional foods contain bioactive compounds associated with the prevention, control, or treatment of chronic diseases [18]. Carotenoids, dietary fibers, fatty acids, minerals, prebiotics, probiotics, symbiotics, and vitamins are among the most commercialized products in the functional food market [18]. Concerning this, there is a certainty that the consumption of probiotic dairy products leads to health benefits such as the reduction of blood cholesterol, and prevention of obesity, diabetes, cardiovascular diseases, and cerebral stroke [17]. For instance, beneficial effects of yoghurt cultures like Lactobacillus delbrueckii subsp. bulgaricus and Streptococcus salivarius subsp. thermophilus have already been widely accepted [15].

However, although milks from animal species such as buffaloes are essential to the human diet in several world areas, the most part of the studies have focused on cow milk. In addition, although there are many studies about the effect that the consumption of probiotics (freeze-dried or powdered pills) has on chronic health conditions, there is hardly any research about probiotics from buffalo milk. Therefore, this review focused on studies that had evaluated buffalo milk characteristics and its products as well as the potential health benefits of the most common microorganisms isolated from raw buffalo milk. The aim of the work is to promote commercially feasible applications of buffalo milk as a probiotic functional food to health-related problems.

\section{Buffalo Milk Characteristics and Its Dairy Products}

It is noteworthy that buffalo milk is richer than cow milk in all major constituents [2,3]. In this regard, its high energy and nutritional value is due to the fact that fat constitutes the main fraction [3,4]. Buffalo milk is also characterized by high levels of lactose, protein, and ash (Table 1). However, wide variations have been recorded with regards to buffalo milk composition. Several studies have monitored compositional changes over the years, finding that they are affected by a combination of environmental, nutritional, and genetic factors $[1-4,10,19,20]$. 
Table 1. Buffalo (Bubalus bubalis) milk chemical composition and nutritional value.

\begin{tabular}{|c|c|c|}
\hline Compound & Value & Reference \\
\hline Milk density $\left(\mathrm{g} / \mathrm{cm}^{3}\right)$ & 1.037 & [2] \\
\hline \multicolumn{3}{|l|}{ Chemical composition } \\
\hline Dry matter $(\%)$ & 16.10 & [2] \\
\hline Solid non-fat (\%) & 10.48 & [2] \\
\hline Protein $(\%)$ & $2.70-5.20$ & {$[3,10,21,22]$} \\
\hline Casein (g/100 mL of milk) & $3.07-3.20$ & [19] \\
\hline Fat $(\%)$ & $6.02-8.80$ & {$[2,3,10,21]$} \\
\hline Lactose (\%) & $4.51-5.36$ & {$[2,3,21,22]$} \\
\hline Total ash $(\%)$ & $0.60-0.90$ & {$[2,3,22]$} \\
\hline Energy $(\mathrm{kJ} / \mathrm{kg})$ & $3450-4.054$ & {$[2,21]$} \\
\hline \multicolumn{3}{|l|}{ Amino acids (g/100 g protein) } \\
\hline Threonine & $1.99-5.71$ & {$[22,23]$} \\
\hline Cysteine & 0.59 & [23] \\
\hline Valine & $6.76-8.28$ & {$[22,23]$} \\
\hline Methionine & $0.93-1.99$ & {$[22,23]$} \\
\hline Isoleucine & $3.32-5.71$ & {$[22,23]$} \\
\hline Leucine & $6.12-9.79$ & {$[22,23]$} \\
\hline Tyrosine & $3.36-3.86$ & {$[22,23]$} \\
\hline Phenylalanine & $3.97-4.71$ & {$[22,23]$} \\
\hline Lysine & $7.50-9.84$ & {$[22,23]$} \\
\hline Cholesterol (mg/100 g of milk) & $6.50-17.96$ & {$[3,24]$} \\
\hline \multicolumn{3}{|l|}{ Fatty acids $(\%)$} \\
\hline $\mathrm{C} 4: 0$ & $3.66-4.18$ & [25] \\
\hline C6:0 & $1.67-2.78$ & [25] \\
\hline C8:0 & $1.82-2.98$ & [25] \\
\hline C10:0 & $1.80-3.21$ & [25] \\
\hline C12:0 & $2.39-3.92$ & [25] \\
\hline C14:0 & $9.96-10.97$ & [25] \\
\hline C16:0 & $26.49-30.17$ & [25] \\
\hline $\mathrm{C} 16: 1 n-7$ & $1.24-2.02$ & [25] \\
\hline C18:0 & $10.78-13.79$ & [25] \\
\hline C18:1n-9 & $23.33-25.17$ & [25] \\
\hline C18:2n-6 & $1.07-1.84$ & [25] \\
\hline SFA & $63.31-68.31$ & [25] \\
\hline MUFA & $25.27-28.32$ & [25] \\
\hline PUFA & $2.43-3.10$ & [25] \\
\hline CLA & $0.41-0.58$ & [25] \\
\hline \multicolumn{3}{|l|}{ Minerals $(m g / 100 g)$} \\
\hline $\mathrm{Ca}$ & $112-148$ & {$[22,26]$} \\
\hline $\mathrm{P}$ & $99-107$ & {$[22,26]$} \\
\hline K & $86-92$ & {$[22,26]$} \\
\hline $\mathrm{Mg}$ & $8-14$ & {$[22,26]$} \\
\hline $\mathrm{Na}$ & $35-37$ & {$[22,26]$} \\
\hline $\mathrm{Zn}$ & $0.41-0.46$ & {$[22,26]$} \\
\hline $\mathrm{Fe}$ & 0.16 & [26] \\
\hline $\mathrm{Cu}$ & 0.04 & {$[22,26]$} \\
\hline $\mathrm{Mn}$ & $0.03-0.07$ & {$[22,26]$} \\
\hline
\end{tabular}

SFA: Saturated fatty acids; MUFA: Monounsaturated fatty acids; PUFA: Polyunsaturated fatty acids; CLA: Conjugated linoleic acid.

Compared to bovine milk, the high content of fat and protein [9] makes buffalo milk a very good raw material for processing, especially cheese making [21]. In relation to lipids, the fat globule size of buffalo milk is larger than other ruminants such as cows, goats, and sheep, which could affect the properties of dairy products $[3,22]$. On the other hand, although buffalo milk has more fat, its cholesterol content is slightly lower than cow's milk. This could be due to the difference in the size of the fat globules [3,9].

Concerning the fatty acid composition, buffalo milk contains higher total saturated fatty acids (SFA) and lower monounsaturated fatty acids (MUFA) than cow's milk fat, 
under similar conditions. The milk of buffaloes also has more conjugated linoleic acid (CLA) [4,22] and its precursors (C18:1n-7 trans and C18:2n-6 cis) [22]. However, despite the differences in the fatty acid composition among these two species, the atherogenic index was almost the same [3].

The major proteins of buffalo milk are $\alpha$ s1-casein, $\alpha$ s2-casein, $\beta$-casein, $\kappa$-casein, $\beta$ lactoglobulin, and $\alpha$-lactalbumin. Unlike cow milk, buffalo milk had higher contents of $\alpha$ s2-casein and $k$-casein ( 2-fold) [22]. In addition, the higher contents of $k$-casein favour the production of cheese, since they allow to accelerate the enzymatic phase of the coagulation of the rennet, and reduce the necessary amounts of chymosin [3,22]. A further difference lays in the average size of the casein micelles, which is larger in buffalo milk [3,22], and in the higher activity of some enzymes such as lactoperoxidase, alkaline phosphatase, and lactoferrin [3,27]. The plasmin activity has been studied in connection with the formation of $\gamma$-caseins from hydrolysis of $\beta$-casein; even though it is not considered to be very different from that in bovine milk, the formation of plasmin-derived fragments of $\beta$-casein has been proposed as a tool to assess milk freshness [28]. As the proteome of buffalo milk is only slightly different from that of cow, there is an antibody cross-reactivity between both types of milk. However, Sheehan and Phipatanakul [12] reported a case of a patient with cow milk allergies capable of tolerating buffalo milk. It was also previously reported that the concentration of all free amino acids, which can easily be absorbed, is higher in buffalo milk than in other milks. Besides, participating in the protein synthesis, amino acids could also have a significant effect on sensory attributes of milk, especially glutamic acid, for the umami taste in cheese [22]. Buffalo milk is often richer in lactose than cow, goat, sheep and camel milk, which would result in a good source of energy for the brain and hormonal regulation [2].

Regarding minerals, buffalo milk is high in calcium (1.5-fold higher than cow's milk) [3,22]. The mineral content of buffalo milk (higher calcium than phosphorus content) may be a matter of concern, since there is a strong correlation between fresh cheese yield and rennet coagulation time concerning these minerals [22]. In addition, buffalo milk is considered a better supplement for infants than bovine milk due to its calcium contents, a better calcium/phosphorus ratio, and a greater protein efficiency ratio [20]. Therefore, buffalo milk has many advantages compared to other species.

Furthermore, milk from buffalo contains more tocopherols, vitamin A [9], and $\delta$ valerobetaine (antioxidant and anti-inflammatory actions) [4] compared to bovine, as well as biliverdin, bioactive pentasaccharides, and gangliosides, which do not appear in the composition of cow's milk [3]. Finally, volatile composition of buffalo milk shows that $50 \%$ of the identified compounds are esters, $14 \%$ aldehydes, $13 \%$ nitrogen compounds, $9 \%$ ketones, 5\% aliphatic alcohols, 2.5\% aromatic, and 4\% sulfur compounds [3]. According to Moio et al. [29], the aroma of water buffalo milk was highly connected to l-octen-3-ol (raw mushrooms), indole (stable, animals), nonanal (freshly cut grass), and with an unidentified compound associated with a typical odour of warm milk and/or smoked cheese.

\section{Probiotics}

The word "probiotic" comes from Greek, and it means "for life" [17]. The initial notion of probiotic microorganisms dates back to a century ago when the Nobel Laureate Elie Metchnikoff suggested in his book "The Prolongation of Life" [30] that the consumption of fermenting bacilli (Lactobacillus bulgaricus) from milk products could positively influence the microbiota of the gut $[31,32]$.

The term "probiotic" was probably invented in 1954 by Ferdinand Vergin in his article entitled "Anti-und Probiotika" [33]. This definition has been modified a lot since then. Nowadays, as already discussed, the most recent definition was formulated from FAO and WHO guidelines [34] and published in 2013 by ISAPP [15]. The most common genera currently used that possess probiotic characteristics are the lactic acid bacteria Bifidobacterium and Lactobacillus [18,32]. Table 2 shows the main microorganisms (bacteria and some yeast) that have been utilized as probiotic cultures. 
Table 2. Microorganisms (bacteria and some yeast) that are used as probiotics.

\begin{tabular}{ll}
\hline Genera & Species \\
\hline & acidophilus, casei, crispatus, delbrueckii subsp. bulgaricus a , \\
Lactobacillus & fermentum, gasseri, johnsonii, paracasei, plantarum, reuteri, \\
& rhamnosus, helveticus, lactis, sporogenes \\
Bifidobacterium & bifidum, breve, infantis, longum, lactis, animalis, \\
& adolescentis, essensis, laterosporus \\
& Escherichia coli Nissle, Saccharomyces boulardii, S. \\
Escherichia, Saccharomyces, & cerevisiae, Kluyveromyces lactis, Streptococcus \\
Kluyveromyces, Streptococcus, & thermophilus a, S. cremoris, S. diacetylactis, S. intermedius, \\
Enterococcus , Propionibacterium, & S. salivarius, Enterococcus francium b, Propionibacterium \\
Pediococcus, Leuconostoc, Bacillus, & freudenreichii, P. freudenreichii subsp. shermanii, P. \\
Clostridium & jensenii, L. lactis, Pediococcus, Leuconostoc lactis subsp. \\
& cremoris, L. lactis subsp. lactis, Bacillus cereus, \\
& Clostridium butyricum \\
\hline
\end{tabular}

$\bar{a}$ poor survival during gastrointestinal transit; ${ }^{\mathrm{b}}$ potential pathogenicity and vancomycin resistance. Adapted from $[18,32]$.

\subsection{Probiotic Strains Required Properties}

The formula of probiotic cultures must be adequate to achieve in sufficient and viable number the target in the host after processing, storage, and gastrointestinal transit [16,35]. In addition to this, it is important to consider the type of carrier/matrix and the interaction between probiotic and starter culture, since it could condition the viability of a particular strain, resulting in a modification of product properties [36,37].

Taking this into account, probiotic strains must meet safety, functional, and technological usefulness criteria with documented pro-health effects consistent with the strain. The safety of a strain is related to the absence of pathogenic cultures and resistance to antibiotics, while its functional properties are related to its survival in the gastrointestinal tract and its immunomodulatory effect. Lastly, technology usefulness means that they must maintain their properties during storage and distribution [17].

In addition to the abovementioned aspect, probiotics are also subject to food regulations. For example, in the USA, the FDA (Food and Drug Administration) grants the GRAS (Generally Regarded As Safe) status to all microorganisms used in food [17]. In Europe, the EFSA utilizes the QPS term (Qualified Presumption of Safety) [38], defined as "an assumption based on reasonable evidence", which allows certain restrictions to apply [39]. This qualification is awarded when a group of microorganisms does not pose safety concerns [40]. In this regard, the EFSA has awarded this qualification only to 32 Lactobacillus species for human applications.

Nowadays, the most studied and employed probiotic microorganisms with proven efficacy for human health are Bifidobacterium animalis, Lactobacillus casei Shirota, Lactobacillus rhamnosus GG, Saccharomyces cerevisiae Boulardii, and as well geni Enterococcus, Lactococus, and Streptococcus $[17,35,41]$. These strains have long been used safely in the food industry [42]. On the other hand, recent advances have been made in the selection and characteristics of new probiotic strains, their possible use, and their health effect [17]. In Figure 1 is shown the selection criteria that should be applied to raw buffalo milk and its products to consider its microbiota as probiotic strains according to the FAO [34] and EFSA [43] concerning its safety, functional, and technological properties. 

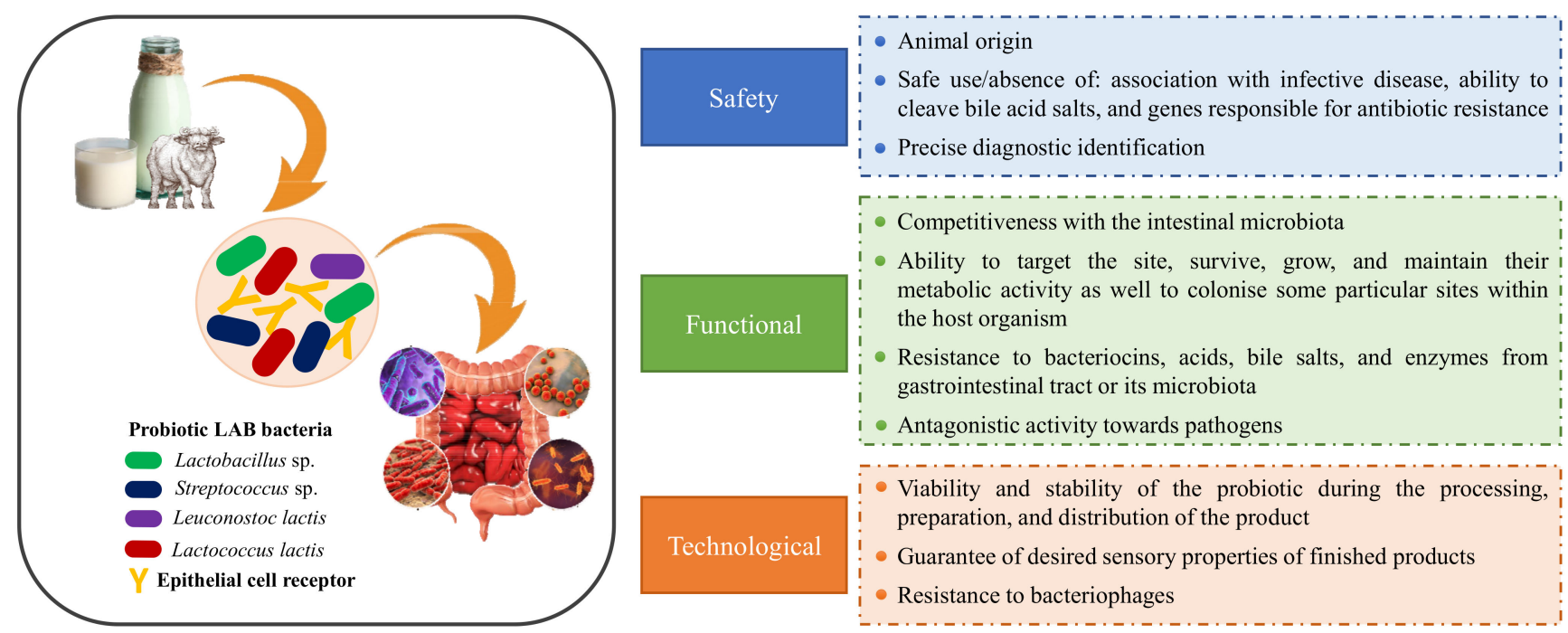

Figure 1. Selection criteria that should be applied to raw buffalo milk and its products to consider its microbiota as probiotic strains concerning its safety, functional, and technological properties. Adapted from [34,43].

Lastly, there is growing concern about the misuse of the term "probiotic", used in many products without meeting the required criteria. This is the case of products such as aftershave, disinfectants, mattresses, or shampoos, where the viability and efficacy of the microbes used has not been taken into account [15]. In addition, sometimes it is difficult to know the contribution of these microorganisms to human health, since sometimes these microorganisms are not well defined in foods and could fall short to be considered probiotics. Therefore, it is recommended to use the statement "contain live and active cultures", and not to misuse the term probiotic [15].

Therefore, as mentioned above, the growing interest in probiotic products has motivated regulatory bodies to protect consumers from the misuse of nutrition and health claims on food. Nevertheless, sometimes a sufficient level of scientific evidence is not reached by agencies responsible for securing health benefits, which makes this process not standardized throughout the world [18]. In this regard, no claims on probiotics are listed on the European Union register as authorised for use.

\subsection{Mechanism of Action and Human Health Effects of Probiotics}

Three mechanisms are responsible for the promotion of human health by probiotics: (i) provide end-products of anaerobic carbohydrate fermentation to the host as well as affect other microbial products such as host products (e.g., bile salts), food ingredients, and toxins; (ii) direct effect on other microorganisms (commensal and/or pathogenic); and (iii) stimulate host immune response (innate and acquired), which is so important in the prevention and treatment of diseases and the eradication of neoplastic host cells. It is important to mention that the health effects of probiotics are not specific to the species or genus, but rather strain-specific $[18,35,44]$. In this case, microorganisms with probiotic effect are unlikely to be a universal remedy for various diseases, since they do not respond at the same time to the three mechanisms of action mentioned above. In this regard, probiotic products can be made up of one or more microbial strains. This selected combination of probiotics would offer a higher level of protection, since it would show several mechanisms of action at the same time.

Despite the fact that, at this time, a consensus has not been established on what is the adequate intake of probiotics [16], the particular advantage of probiotics is their mechanisms of action. Probiotics efficacy is directly associated with their effect on other microorganisms (e.g., pathogens) and the balance of the host's intestinal microbiota. Their ability could promote the formation of a protective barrier, which would prevent the colonization of the epithelium by pathogenic bacteria, protecting the host from toxins as well as 
causing the activation of immune cells [17,35]. Immunological stimulation of probiotics can consist in an increasing production of immunoglobulins and $\gamma$-interferon, macrophages and lymphocytes activity. In addition, the components of the cell wall of lactic acid bacteria (LAB) can encourage the activity of macrophages, which would increase the production of free oxygen radicals and lysosomal enzymes, destroying microbes rapidly [17]. Thus, as already discussed, the consideration of a microorganism as a probiotic depends mainly on the ability of a strain to survive through the GI tract and colonise the intestine.

At the same time, there are several techniques to maintain the viability of these microorganisms in the intestinal system. Among them, the addition of growth promoters (e.g., prebiotics) or the use of microencapsulation techniques stand out [18]. Prebiotics are described as a non-viable food component that modulates the microbiota in order to give a health benefit to the host [45]. There are many studies that demonstrate the beneficial effects of prebiotics, highlighting the results achieved with the combined use of probiotics and prebiotics. The resulting food is known as "synbiotic", whose purpose is to improve the survival of probiotic microorganisms in the GI tract. The most promising prebiotic substances are oligosaccharides such as fructooligosaccharides, galactooligosaccharides, isomaltooligosaccharides, xylooligosaccharides, transgalactooligosaccharides, and soybean oligosaccharides $[17,35]$.

On the other hand, concerning probiotic encapsulation, the most common methods are extrusion, emulsion, coacervation, lyophilization, and spray drying. Probiotics encapsulation can promote the viability and functionality of microorganisms in food products. The microencapsulation technique is presented as a great alternative to maintain probiotic viability during food processing and its passage through the gastrointestinal tract. In addition, this technique can mask unpleasant flavours and odours, thus increasing the product shelf life [31].

In contrast, the disadvantages arising from the use of probiotics have sparked interest in the development of non-viable probiotic preparations. There is a growing conviction that the benefits attributed to physiologically active bacteria are not strictly associated with their viability. Recent studies have suggested to this preparation terms such as paraprobiotic (from "probiotic paradox"), non-viable, inactivated, tyndallized or ghost probiotics. Paraprobiotics are defined as non-viable microbial cells or raw cell extracts that could lead to health benefits when consumed in adequate amounts [16].

\subsection{Probiotic Microorganisms of Buffalo Milk}

Raw milk can contain a diverse bacterial population. In addition, its high nutrient content with a high-water activity at a near-neutral $\mathrm{pH}$ promotes the growth of many microorganisms. However, despite the fact that the microbial community within milk is complex, many raw milk isolates can contribute to the technological properties of dairy products and its health-promoting abilities [11]. This specific microbiota is going to condition the development of dairy products and, among probiotics, dairy products are the key product sector [42]. LAB (e.g., Lactococcus, Streptococcus, Pediococcus, and Enterococcus) are the main probiotic group, while lactobacilli and bifidobacteria (usually found as commensals in the human gastrointestinal tract) comprise the most used and recognized probiotic microorganisms [18,31].

Concerning buffalo milk, it is generally accepted that, prior to pasteurization, LAB species are the dominant bacterial population. Lactobacillus, Lactococcus, Streptococcus, Leuconostoc, and Enterococcus are the most common LAB in buffalo milk [11]. The microbial content less prevalent but frequently isolated from raw buffalo milk also includes psychrotrophic populations (Pseudomonas and Acinetobacter spp.), which particularly establish themselves during cold storage, Staphylococcus species, and Escherichia coli [11]. Nevertheless, some probiotics create uncertainty about their safety. This is the case of the genus Enterococcus, which can be pathogenic and cause disease in the host [32]. The potential human health benefits as well the mechanism of action of the most common LAB probiotics isolated in raw buffalo milk are shown in Figure 2. 


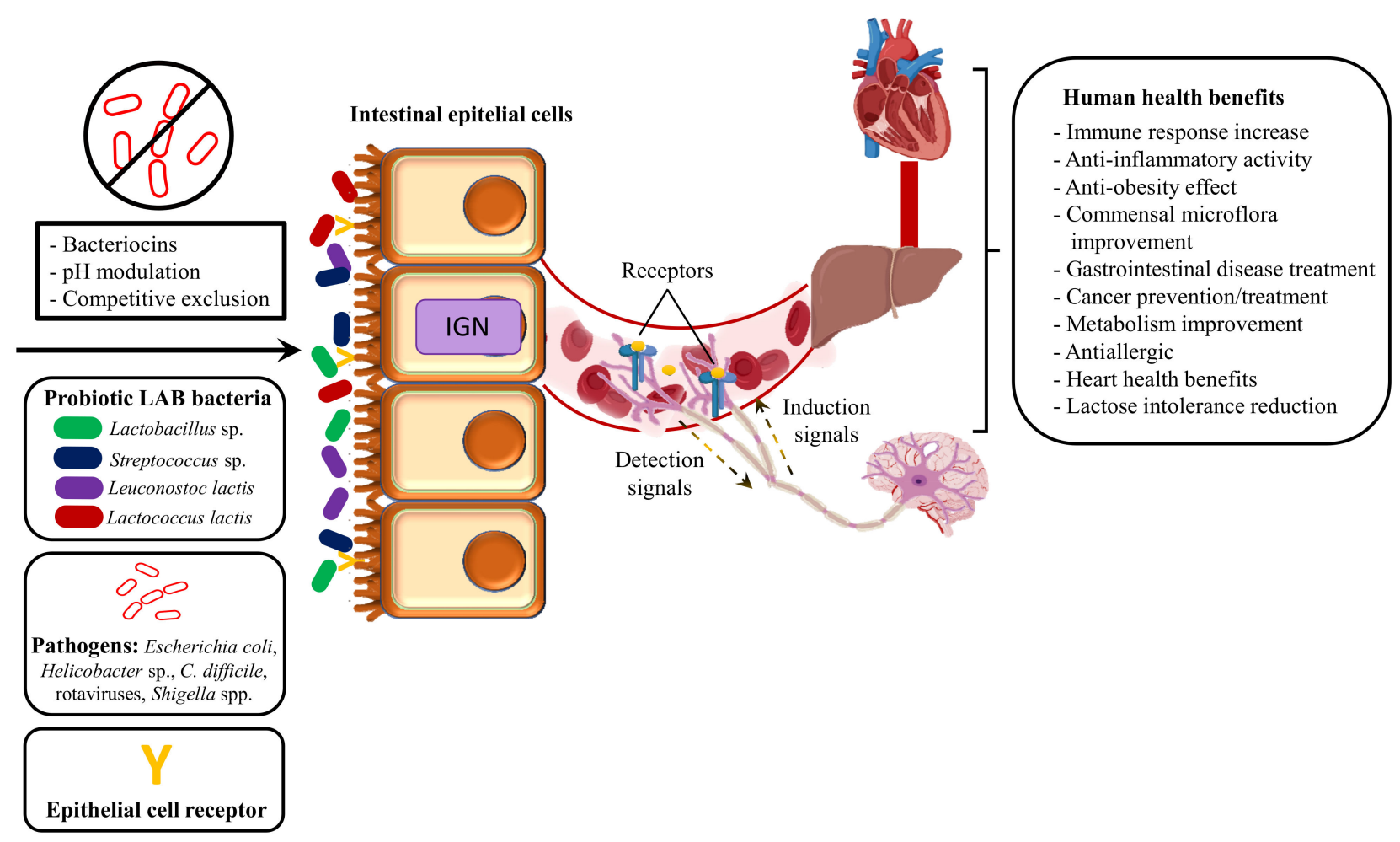

Figure 2. Mechanism of action and human health benefits from the main lactic acid bacteria (LAB) isolated from raw buffalo milk (Lactobacillus sp.: L. plantarum, L. paracasei, L. fermentum, L. delbrueckii; Streptococcus sp.: S. thermophilus, S. macedonicus).

The main beneficial effect of probiotics is to repair the gut microbiota, which allows to improve gut and immune homeostasis. Along with these, probiotics can have modulatory effects on CNS disorders (anxiety, depression, and ASD) through modifications in the gut microflora composition [46]. In this regard, several studies have demonstrated that gut microbiota has a key role in the gut-brain axis. This bidirectional interaction between microbiota and brain receives the name of microbiota/gut-brain axis.

The most studied microorganisms isolated from raw buffalo milk with probiotic and/or technological effects in dairy products (Lactobacillus sp., Streptococcus sp., Lactococcus lactis, Leuconostoc lactis, and Pseudomonas fragi) are discussed in more detail below.

\subsubsection{Lactobacillus}

There are several isolates of dairy lactobacilli bacteria that have demonstrated effective as probiotic strains. The inhibition of pathogenic organisms, the reduction of lactose intolerances and the increase of the immune response are associated with probiotics of the genus Lactobacillus [11]. Lactobacillus genera can produce bacteriocins and some antibiotics, such as the so-called de-conjugated bile acids, which display higher antibacterial effects than those shown by bile salts produced by their host [44]. The main Lactobacillus species with probiotics properties isolated from buffalo milk are L. plantarum, L. paracasei, L. fermentum, L. delbrueckii, and L. kefiranofaciens [11].

The genus Lactobacillus exhibits a level of genetic diversity superior to that found in other bacterial genera. Since 2015, several large-scale phylogenetic analyses, based on the phylogeny of the central genome, have revealed the discrepancy between these taxonomies. Therefore, the taxonomy of Lactobacillus has been changed to create a genus with a better homogeneity between organisms. The new classification, based on various approaches and genetic markers [47], provides a better ecological and functional vision that even can improve the way the industry develops products.

L. plantarum (now known as Lactiplantibacillus plantarum) is a natural producer of bacteriocins and B group vitamins [48]. The production of bacteriocins from this microorganism 
could improve the safety and increase the quality of dairy products [44]. L. plantarum also enhances the absorption of vitamins and minerals as well as stimulates the generation of organic acids and amino acids. In addition, these probiotic increases provide protection against pathogens (e.g., blocking adherence of pathogens or by mucin production) and the efficiency of the immune system $[17,44]$. It was previously reported that L. plantarum competes with pathogens (e.g., Helicobacter sp., Clostridium difficile, rotaviruses, Shigella spp., and E. coli) for receptor sites in the GI tract more effectively than that achieved by other species. In addition, reduction in luminal $\mathrm{pH}$, competition for nutrients, and production of beneficial volatile compounds are the main mechanisms responsible for the competitive exclusion of pathogens [49]. Finally, teichoic acid from the cell wall of L. plantarum could be related to its anti-inflammatory activity [44].

It was previously reported that L. paracasei consumption had anti-obesity effects with body weight, body fat, and feed efficiency decrease, probably due to the reduction of the average radius and the consequent increase in the number of small adipocytes [50]. In addition, L. paracasei could improve immune function by enhancing the systemic immune response to challenges, like vaccinations in healthy subjects. Particularly, previous studies suggested that daily consumption of yoghurt containing L. paracasei could improve immune function by enhancing NK cell activity [51]. Increased concentrations of innate and acquired immunity biomarkers have been reported after the use of L. paracasei, with short-chain fatty acids and volatile compounds (e.g., faecal butyrate) modulation, and were also reported as beneficial effects of this probiotic against diarrhea and constipation [49].

Nowadays, there is a growing interest in the health benefits of polyphenols (e.g., ferulic acid), since several properties are associated with them such as antidepressant, anti-inflammatory, neuroprotective, antihyperglycemic, anticancer, and antidiarrheal properties [52]. However, natural sources of ferulic acid are not readily bioavailable and must be released enzymatically to be absorbed by human digest. L. fermentum (now known as Limosilactobacillus fermentum) is characterized by a high ferulic acid esterase activity [53]. Therefore, orally ingested microencapsulated ferulic acid esterase produced by Lactobacillus could increase bioavailability of ferulic acid [53].

Iron is considered a limited substance in the host. In fact, excluding lactobacilli, it is a crucial compound for many bacteria. L. delbrueckii conditions the activity of other microorganisms by binding iron hydroxide to its surface, which would make it no longer available to other pathogenic microorganisms. This gives this probiotic a very important advantage over other microorganisms that depend on this mineral [44]. L. delbrueckii can become established in the gut and progressively control the natural microflora. This microorganism is also able to resist acidity and reach the intestine in a viable state, which would avoid the presence of pathogens microorganisms, protecting the intestinal health of the host [54].

L. kefiranofaciens is one of the microorganisms that dominates the microflora of kefir and kefir grains, being able to produce kefiran. Previous studies published that L. kefiranofaciens is highly stress-tolerant (during industrial processes and digestive transit), to heat $\left(52{ }^{\circ} \mathrm{C}\right)$, cold $\left(-20^{\circ} \mathrm{C}\right)$, acid ( $\left.\mathrm{pH} 3.0\right)$, and bile salts (0.2\%) [55]. In addition, it was also reported that L. kefiranofaciens inhibits the growth and formation of biofilms against microbes, which causes dental caries, as well as palliate the enterohaemorrhagic action of E. coli (EHEC) infection, bacterial translocation, and intestinal and renal dysfunction [56].

\subsubsection{Streptococcus}

Streptococcus thermophilus is the second most important specie of industrial LAB after Lactococcus lactis. This probiotic has GRAS status and is extensively used for the fermented dairy foods processing. S. thermophilus has several functional activities such as the production of extracellular polysaccharides, bacteriocins, and vitamins, as well as several health effects, transient survival, and moderate adherence in the GI tract [57]. S. thermophilus has similar mechanisms of action compared with those already discussed for L. delbrueckii. This microorganism can also establish and dominate the natural microflora 
of the intestine of the host due to its resistance to acidity, protecting the intestinal health of the consumer [54]. In addition, the $S$. thermophilus strain generates large amounts of folate, necessary in DNA repair of epithelial cells [44]. S. thermophilus can signal an immune regulatory processes and improved mucosal barrier injury, reducing the levels of pro-inflammatory factors and cytokines as well as neutrophil infiltration [49].

The recently described Streptococcus macedonicus is among the microorganisms similar to Streptococcus thermophilus. This dairy streptococcus possesses a food grade and has no potential pathogenicity. Certain strains of $S$. macedonicus produce bacteriocins named macedocin (a food-grade lantibiotic) and exopolysaccharides. However, S. macedonicus does not survive the low $\mathrm{pH}$ conditions of the stomach [58].

\subsubsection{Lactococcus, Leuconostoc and Pseudomonas}

From Lactococcus genera, Lc. lactis is the most important specie. This bacteria is considered to be the most important specie of industrial LAB [57]. Fermented milk with Lc. lactis was previously reported as providing heart health benefits in vitro, attenuating blood pressure, cholesterol (LDL), and triglycerides levels. Hence, authors concluded that daily consumption of fermented milk with Lc. lactis could be used as a potential functional food [59]. In addition, Lc. lactis is able to survive in low $\mathrm{pH}$ conditions, bile salts, and self-aggregating and co-aggregating with E. coli, making this microorganism a potential probiotic starter culture [60].

Concerning Leuconostoc lactis, a previous study suggested that this microorganism would allow to produce a new and safe functional product by hydrolysing milk casein during fermentation. This probiotic showed the ability to develop an active peptide with antioxidant $[61,62]$ and angiotensin-I converting enzyme inhibitory activity (ACE-I). The active peptide (MVPYPQR) produced during fermentation could be used as an ingredient in nutraceuticals and functional foods [61].

Pseudomonas species are the most commonly found psychrotrophs in chilled raw milk because of inadequately disinfected milking equipment [63]. Pseudomonas fragi is recognised as a common agent that contributes to the spoilage of pasteurised and UHT milk through the activity of thermostable extracellular proteases and lipases. In consequence, this microorganism can limit the shelf life of milk and its products (e.g., cheese) because of fruity off-odours as a result of the production of methyl esters, in particular, short-chain ethyl esters. In addition, some $P$. fragi isolates also produce extensive amounts of volatile compounds such as methyl and ethyl acetate, ketones, alcohols, 1-undecene, and sulphur compounds $[63,64]$. In order to maintain the quality of the dairy products, controlling the growth of Pseudomonas and their activity in milk prior to heat treatments is of great importance $[64,65]$.

\section{Functional Food: Milk-Based Products from Buffaloes}

The diet provides the necessary nutrients to meet metabolic needs. However, growing concern for health and well-being is increasing the demand for functional foods, which has motivated the change in the way of conceiving food [35]. This is also reflected in the interest in oral probiotics and their effects on the gut microbiota [31]. Functional food can be defined as "Similar-looking foods to conventional food intended to be part of a normal diet, which has been enhanced to offer physiological functions beyond the provision of the nutrient requirements" [42].

Originally, the functionality of functional foods was based on bioactive components that are often already part of the food. Today, probiotics, prebiotics, vitamins, and minerals are also included among these functional ingredients, which are commonly used in developing dairy products $[32,35]$. However, the viability of probiotics in food is a critical factor. Therefore, some food matrices are more suitable to deliver probiotics than others. The buffering capacity of milk and milk fat guarantees the survival of probiotics throughout the production process. Hence, dairy products rich in milk fat, including yoghurt (a very efficient probiotic vehicle), cheese, and frozen fermented dairy desserts, represent an ideal and 
marketable carrier of functional food [16,35]. To ensure the declared benefits, it is necessary that, at the time of consumption, the probiotics be viable and sufficiently abundant [66]. In addition, to have a therapeutic effect, it must contain at least $10^{6}-10^{7} \mathrm{CFU} / \mathrm{g}$ of probiotic bacteria, or a total of $10^{8}-10^{9} \mathrm{CFU}$, taking into account an approximate daily consumption of $100 \mathrm{~g}$ or $100 \mathrm{~mL}$ of probiotic food [31].

Buffalo milk can be used to make a wide variety of dairy products, since it contains less water and more fat, which is especially useful for the production of dairy products. In addition, buffalo milk is also ideal for the manufacture of these products due to the larger globule size and the higher proportion of solid fat [2]. In this sense, fermented dairy foods such as yoghurt and cheese have been traditionally associated with functional food, since they are the major vehicle in delivering probiotics [18,32]. In addition, fermented milk is one of the best matrices to elaborate functional foods, since it has a high sensory acceptance and a long shelf life [66]. The potential technological properties in dairy products from the most common probiotics microorganisms isolated in raw buffalo milk are shown in Table 3.

Table 3. Main microorganisms isolated in raw milk of buffalo (Bubalus bubalis) with probiotic and/or technological properties in dairy products.

\begin{tabular}{|c|c|c|c|c|}
\hline Genera & Species & Technological Effects & Products & Ref. \\
\hline \multicolumn{5}{|c|}{ Most prevalent } \\
\hline Lactobacillus & $\begin{array}{l}\text { plantarum }^{(Q)}, \text { paracasei }^{(Q)}, \\
\text { fermentum }^{(Q)}, \text { delbrueckii }^{(Q)}, \\
\text { kefiranofaciens }^{(Q)}\end{array}$ & $\begin{array}{l}\text { Proteolysis, lipolysis, and } \\
\text { aroma compounds }\end{array}$ & Cheese & [11] \\
\hline Lactococcus & lactis $^{(Q)}$ & $\begin{array}{l}\text { * Starter cultures; flavour } \\
\text { compounds; acidification; } \\
\text { proteolysis; citrate utilisation; } \\
\text { fat metabolism; bacteriocin } \\
\text { production. } \\
\text { *Starter culture; lactose to }\end{array}$ & Cheese & [11] \\
\hline Streptococcus & thermophilus ${ }^{(Q)}$, macedonicus & $\begin{array}{l}\text { lactate; exopolysaccharide and } \\
\text { bacteriocins production. }\end{array}$ & Yoghurt, cheese & [11] \\
\hline \multicolumn{5}{|c|}{ Less prevalent } \\
\hline Leuconostoc & $\operatorname{lactis}^{(Q)}$ & $\begin{array}{l}\mathrm{CO}_{2} \text { production; lactose and } \\
\text { citrate metabolization; } \\
\text { bacteriocins production. }\end{array}$ & - & [11] \\
\hline Pseudomonas & fragi & $\begin{array}{l}\text { Spoilage via heat-stable } \\
\text { enzymes and fruity off-odour. }\end{array}$ & Milk and its products & {$[63,64]$} \\
\hline
\end{tabular}

* Streptococcus thermophilus. (Q) QPS (Qualified Presumption of Safety) microorganisms [67].

On the other hand, it is important to highlight that most of the dairy products described in this review are from pasteurized buffalo milk (or similar heat treatment) and, therefore, the probiotic microorganisms from raw milk become inactive after processing. The most studied dairy products in which probiotic microorganisms isolated in raw milk of buffalo are commonly utilized (cheese, yoghurt, kefir, butter, and dairy beverages) are further discussed below.

\subsection{Cheese}

Cheese provides a favourable environment to maintain the viability of the probiotic strains until the moment of consumption [18]. In this sense, several studies have shown the possibility of making different types of cheeses with various types of probiotic strains. This allows dairy industries to diversify their products in an increasingly competitive market.

Concerning buffalo milk used for the manufacture of dairy products, it is highly appreciated for its chemical composition that determines its nutritional properties and its suitability to produce functional products. In this regard, the high variability of triglycerides and fatty acids allows to separate fat into various fractions based on its melting 
characteristics. Thus, its high content of high-melting triglycerides contributes to its higher density and makes it suitable for making cheese [2].

In Italy, mozzarella cheese is usually manufactured with buffalo milk, as well as in Balkan countries where white-brined and pickled cheeses are made from this product [2]. In relation to buffalo cheese nutritional value, Becskei et al. [2] observed that lysine was the major amino acid, followed by branched amino acids (valine, isoleucine, and leucine), which promote protein synthesis and are metabolized for energy in the muscles rather than the liver. Among the non-essential amino acids, glutamic acid was the one that showed the highest content in this product.

In relation to probiotic microorganisms, buffalo mozzarella is characterized by the presence of Lactobacillus and Streptococcus genera [68]. S. thermophilus, L. delbrueckii, and L. helveticus, followed by Acinetobacter and Pseudomonas sp., are the predominant bacteria. On the other hand, as already discussed, improvements are needed in the production of hard cheese from buffalo milk in order to maintain the desirable viability of probiotic cultures because of the processing that includes heat treatment and mucor rennet as methods [2].

In addition, improvements are also necessary if it is intended to use probiotic bacteria such as $S$. macedonicus. For example, the optimum temperature $\left(20-25^{\circ} \mathrm{C}\right)$ for macedocin (a biopreservative bacteriocin) production by S. macedonicus is noticeably below that of growth $\left(42^{\circ} \mathrm{C}\right)$. In contrast, the $\mathrm{pH}$ reached at the start of milk fermentation for macedocin production is almost the same as that for growth ( $\mathrm{pH}$ 6.4). Besides, macedocin is retained in the matrix since part of its activity is associated with the curd fraction (after drainage of the whey). Moreover, salt and oxidative stress enhances specific bacteriocin production [58]. Therefore, the conditions for growth and bacteriocin synthesis by S. macedonicus could be promising for their effective application in several cheese varieties from buffalo milk, if improvements are applied.

Finally, it is worth noting the usefulness of S. macedonicus as adjuvant or co-culture, since it intervenes in the hydrolysis of fats and casein, and in the consumption of citrate. Previous studies demonstrated that mixing starter cultures of $S$. thermophilus and S. macedonicus would be useful for designing new starter formulations [58].

\subsection{Yoghurt}

Bovine milk is the most popular raw ingredient to produce yoghurt, but also several studies have been conducted on buffalo yoghurt due to the differences between their composition and physical properties [69].

Yoghurt is made using a mixture of thermophilic starter cultures based on L. delbrueckii and S. thermophilus. Recently, other starter cultures such as L. acidophilus and Bifidobacterium spp. have been included [69]. A higher proteolytic activity was observed when using buffalo milk. This would be due to a better growth of S. thermophilus and L. bulgaricus, and a higher titratable acidity. Moreover, the yoghurt produced with buffalo milk has excellent nutritional properties, which is related to the fact that this product generally has properties similar to the milk with which it is made [20]. In this regard, the yoghurt produced with buffalo milk would be more nutritious due to its higher concentration of protein and fat [69].

In addition, the higher concentration of milk fat and calcium could positively condition the viability of Lactobacillus and Bifidobacterium by stimulating the growth of LAB [70]. This viability can also be increased using higher concentrations of lactose, which would act as a protective layer [69]. Finally, it is important to highlight that the extension of shelf life is limited in probiotic yoghurt due to the oxidative stress suffered by probiotic bacteria. In this regard, many cultured dairy products do not meet the first criterion for probiotics, e.g., "containing live microorganisms" at consumption time, because probiotic strains cannot endure the acidity, which can even increase when it contains lactic acid-producing bacteria [16]. 


\subsection{Kefir}

Kefir is a fermented milk produced by a group of bacteria and yeasts (e.g., with kefir grains). This microbial fermentation can be carried out in a traditional or commercial way [71]. Concerning the artisanal production, the milk is inoculated with a variable quantity of grains that are sieved at the end of the fermentation process, and they could be used for a new fermentation or kept in fresh milk. The initial inoculum concentration of the grains affects the microbiological profile of the final product [72]. Kefir has been associated with health benefits such as anti-allergenic, anti-asthmatic, anticancer, antimicrobial, anti-stress, cholesterol-lowering, immune-modulation, and gastrointestinal beneficial effects [71].

The microbial flora of kefir contains acetic acid bacteria, LAB (Acinetobacter, Enterobacter, Enterococcus, Lactobacilli, Lactococci, Leuconostocs, Pseudomonas spp. and Streptococci), and yeasts (Candida, Kluyveromyces, Rhodotorula, Saccharomyces, Torulopsis and Zygosaccharomyces). In addition, the kefir's properties depend especially on the milk used and its origin and production method [56]. The effects of buffalo milk on kefir characteristics were previously reported by Gul et al. [71], who found higher counts of Lactococci and yeast in kefir samples made from buffalo milk than those made from cow's milk at the end of the storage period.

\subsection{Butter and Ghee}

Butter and ghee (butter oil) are popular dairy products made from buffalo milk in several countries $[9,73]$. Buffalo milk produces a whiter butter than cows' milk due to the lack of carotenoids [74], with a higher level of saturated fatty acids (harder product) and yield. In addition, it has higher stability because of the slower rate of fat hydrolysis (free fatty acids release) [2,75]. However, probiotics are most commonly used in plantbased butters such as peanut butter and butters from coconut, flaxseed, and sunflower oils. Although, recent studies have suggested the utilisation of probiotic bacteria (Bifidobacterium bifidum, Lactobacillus acidophilus, and L. maltaramicus) in butter elaborated from milk [76,77]. Conversely, probiotics strains usually isolated from commercially available fresh butter are not present in raw buffalo milk. On the other hand, probiotic microorganisms of buffalo milk L. delbrueckii and S. thermophilus were recently isolated from homemade butter and reported as starter cultures to butter fermentation processing [77]. To obtain the beneficial effects of butter as a functional food is recommend its consumption level at $25 \mathrm{~g}$ per day [76].

\subsection{Dairy Beverages}

Dairy beverages are products made by blending milk with whey, vegetable fat, fermented milk, and other products [36]. The majority of the probiotic dairy beverages can be categorized into fermented products [32]. The production of beverages based on buffalo milk would allow to expand the range of products, offering different qualities to those of products traditionally made with cow's milk.

A previous study comparing probiotic dairy beverages between buffalo and cow products evaluated the viability of the common microorganisms used to produce fermented dairy products $S$. thermophilus, L. bulgaricus, and L. acidophilus during storage as well their resistance to in vitro gastrointestinal conditions. LAB showed viable cell counts at the end of shelf life with higher values for buffalo dairy products, which suggested the beneficial protective effect on human microbiome that this product might have compared to cow products [36].

\section{Health Effects of Probiotics}

Evidence of human health benefits in favour of probiotics has been extensively investigated $[15,17,18,31,44,49,66,78]$. Meanwhile, it is necessary to highlight that the probiotics benefits are strongly related to the probiotic strains. In addition to probiotics, bioactive compounds produced by fermentation would also have health benefits [66]. Taking this 
into account, Table 4 summarises the probiotic strains that are commonly found in raw buffalo milk and their potential health benefits if consumed as raw milk and/or dairy products as functional food.

Table 4. Potential human health benefits from probiotics microorganisms isolated from raw buffalo (Bubalus bubalis) milk on functional foods.

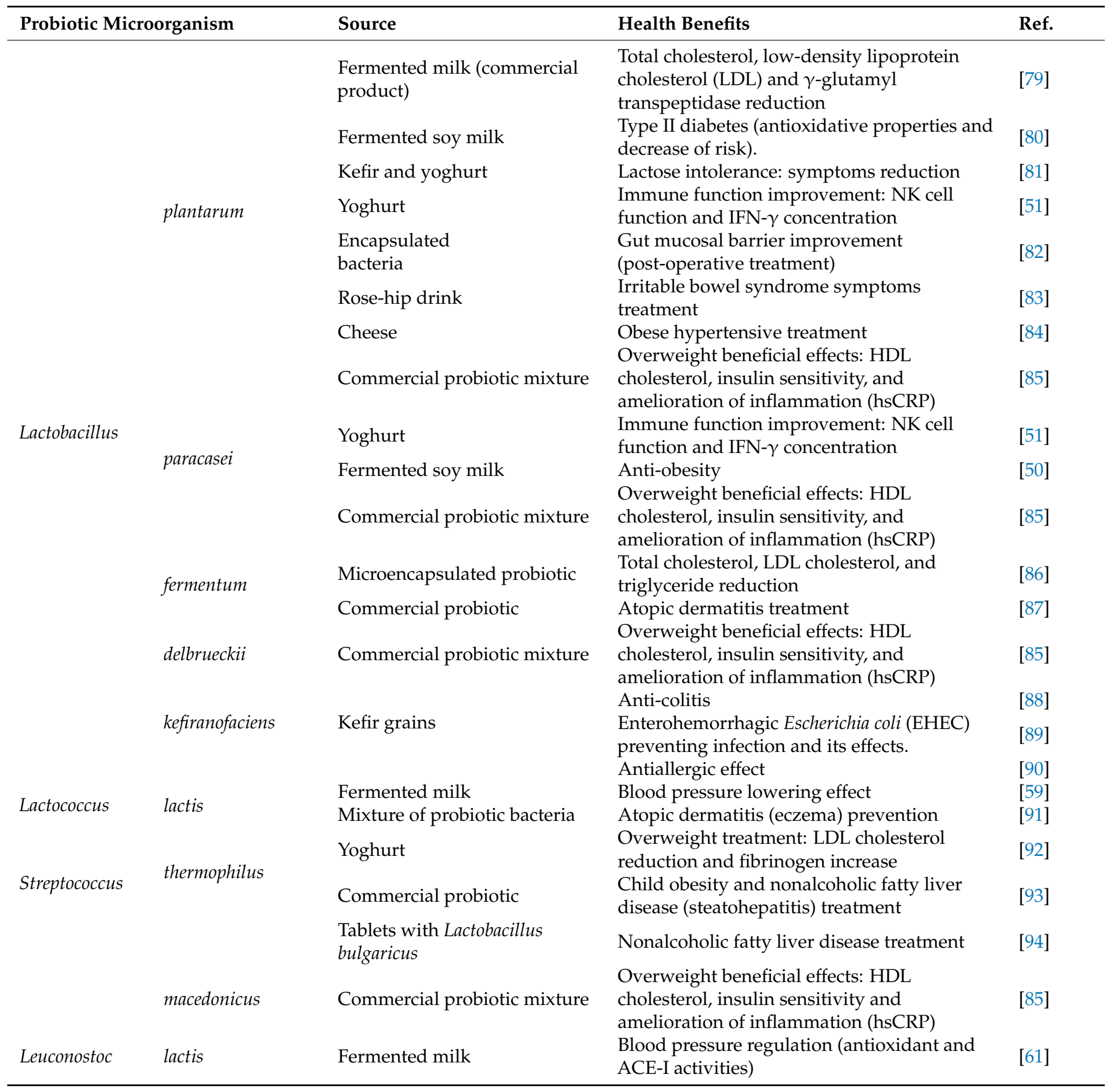

Lastly, with the expansion of the healthcare industry globally, the market for probiotics is expected to continue to grow in the world (mainly in Asia) [31]. Also, over time, the perspective on meeting hunger needs, survival, and anticipating adverse effects has changed towards the use of foods that increase the state of well-being, improving health and reducing the risk of suffering from some diseases. It is important to attend to these aspects, especially taking into account the increase in medical care in some countries [66]. 


\section{Probiotic Adverse Effects}

Concerning intake of probiotics (live microorganisms), bacteraemia and fungemia are among the most frequent ailments, although this list is expected to be expanded in the near future. The main concerns include the possible transfer of genes from pathogenic bacteria in the intestine, the specific properties of the strain, and the competition with the intestinal microflora. Bearing this in mind, food safety is a relevant challenge in the production of probiotics, especially taking into account that the coming generation of probiotics will incorporate new species such as Akkermansia muciniphila, Faecalibacterium, and Bacteroides species [16].

In addition, the possible adverse effects of probiotics are also a matter of concern, especially those that could affect risk groups. Their consumption in high concentrations could cause immune disorders by negatively influencing the balance of cellular functions. Even if rare, cases of mortality, sepsis, endocarditis, pancreatitis, and bowel ischemia have been registered [16].

\section{Other Functional Properties of Buffalo Milk}

Milk and dairy products are a major source of bioactive peptides. These compounds are small molecules that can be present in foods and can positively modulate human health, exerting beneficial effects (e.g., anticancer, antidiabetic, antihypertensive, antimicrobial, antioxidant, and immunomodulatory properties) [9]. In this regard, peptides participate in several physiological tasks such as cardiovascular, endocrine, gastrointestinal, immune, and nervous functions. Based on the peptidomic profile of buffalo-milk dairy products, Basilicata et al. [9] found a large number of peptides with particular bioactivities and proven health benefits. Considering this, these findings would allow the isolation of new active compounds by the pharmaceutical industry, as well as the development of healthy products using buffalo milk as a functional ingredient. this functional matrix could even be combined with other compounds to achieve a synergic or additive associations.

Furthermore, the nutritional and functional value of buffalo milk can also be ascribed due to the presence of a $\delta$-valerobetaine, short-chain acylcarnitines, and L-carnitine. These compounds can confer to the milk consumer a high antineoplastic, antioxidant, and antiinflammatory effect [95]. In addition, buffalo milk also contains $\gamma$-butyrobetaine and L-carnitine precursors [4].

\section{Conclusions and Future Perspectives}

It is a challenge to maintain the standard limit and the viability of probiotics on functional foods (e.g., dairy products) until the end of its shelf life, as well as during the transit through the gastrointestinal tract of the consumer. Consequently, the enormous relevance currently devoted to the functional foods increased interest in maintaining the viability of probiotics and developing new types of oral delivery systems.

In this sense, microencapsulation allows to improve the viability and functionality of probiotics, and constitutes a key research niche. The microencapsulation technique is presented as a great alternative in maintaining probiotic purpose. Additionally, another challenge is using adequate methodologies to assess the efficacy of probiotic microorganisms and ensure their positive health effect. Their application must necessarily go through the correlation of the biological response with the physical condition and vitality of the microbial species.

In conclusion, this review presents the latest discussions on the probiotic microorganisms of raw buffalo milk and its milk-based products application as functional food. Numerous scientific reports confirm that probiotic organisms are key to the balance of the gut microbiota and have a positive effect on the host's health. Besides, probiotics had an already recognized application in dairy products, which is a great opportunity for the functional food development.

In line with this, our review confirms that buffalo raw milk has several probiotic microorganisms and it could be satisfactorily used in the production of high-quality tradi- 
tional dairy products, giving them added value and beneficial health characteristics. Buffalo milk has also shown better physicochemical, compositional, and nutritional attributes than cow's milk. Furthermore, a wide dissemination of the abovementioned proposal for buffalo milk could actively contribute to the promotion of sustainable livestock exploitation, encouraging the genetic diversity and assessment of different breeds for food production.

Finally, with the aim to explore several benefits from the most important livestock that provides milk used by humans for dairy products (e.g., cow, buffalo, goat, sheep, and camel), mixing different types of milk to develop functional foods with enhanced sensorial properties as well improve their health benefits could be an interesting alternative for future research.

Author Contributions: Conceptualization, M.F., P.D.P. and J.M.L.; writing-original draft preparation, M.V.-R.; writing-review and editing, M.P., A.M., and D.F.; supervision, M.F., P.D.P. and J.M.L. All authors have read and agreed to the published version of the manuscript.

Funding: This research received no external funding.

Data Availability Statement: Data are contained within the article.

Acknowledgments: Thanks to GAIN (Axencia Galega de Innovación) for supporting this research (grant number IN607A2019/01).

Conflicts of Interest: The authors declare no conflict of interest.

\section{References}

1. Noce, A.; Qanbari, S.; González-Prendes, R.; Brenmoehl, J.; Luigi-Sierra, M.G.; Theerkorn, M.; Fiege, M.A.; Pilz, H.; Bota, A.; Vidu, L.; et al. Genetic diversity of Bubalus bubalis in Germany and global relations of its genetic background. Front. Genet. 2021, 11, 1664. [CrossRef]

2. Becskei, Z.; Savić, M.; Ćirković, D.; Rašeta, M.; Puvača, N.; Pajić, M.; Dordević, S.; Paskaš, S. Assessment of water buffalo milk and traditional milk products in a sustainable production system. Sustainability 2020, 12, 6616. [CrossRef]

3. Abd El-Salam, M.H.; El-Shibiny, S. A comprehensive review on the composition and properties of buffalo milk. Dairy Sci. Technol. 2011, 91, 663-699. [CrossRef]

4. Salzano, A.; Neglia, G.; D’Onofrio, N.; Balestrieri, M.L.; Limone, A.; Cotticelli, A.; Marrone, R.; Anastasio, A.; D’Occhio, M.J.; Campanile, G. Green feed increases antioxidant and antineoplastic activity of buffalo milk: A globally significant livestock. Food Chem. 2021, 344, 128669. [CrossRef]

5. Mota-Rojas, D.; Braghieri, A.; Álvarez-Macías, A.; Serrapica, F.; Ramírez-Bribiesca, E.; Cruz-Monterrosa, R.; Masucci, F.; MoraMedina, P.; Napolitano, F. The Use of Draught Animals in Rural Labour. Animals 2021, 11, 2683. [CrossRef] [PubMed]

6. FAO Livestock Primary. Available online: https://www.fao.org/faostat/en/\#home (accessed on 23 July 2021).

7. Cesarani, A.; Biffani, S.; Garcia, A.; Lourenco, D.; Bertolini, G.; Neglia, G.; Misztal, I.; Macciotta, N.P.P. Genomic investigation of milk production in Italian buffalo. Ital. J. Anim. Sci. 2021, 20, 539-547. [CrossRef]

8. Borghese, A. Buffalo livestock and products in Europe. Buffalo Bull. 2013, 32, 50-74.

9. Basilicata, M.G.; Pepe, G.; Sommella, E.; Ostacolo, C.; Manfra, M.; Sosto, G.; Pagano, G.; Novellino, E.; Campiglia, P. Peptidome profiles and bioactivity elucidation of buffalo-milk dairy products after gastrointestinal digestion. Food Res. Int. 2018, 105, 1003-1010.

10. Zicarelli, L. Buffalo milk: Its properties, dairy yield and mozzarella production. Vet. Res. Commun. 2004, 28, 127-135. [CrossRef]

11. Quigley, L.; O'Sullivan, O.; Stanton, C.; Beresford, T.P.; Ross, R.P.; Fitzgerald, G.F.; Cotter, P.D. The complex microbiota of raw milk. FEMS Microbiol. Rev. 2013, 37, 664-698.

12. Sheehan, W.J.; Phipatanakul, W. Tolerance to water buffalo milk in a child with cow milk allergy. Ann. Allergy Asthma Immunol. 2009, 102, 349. [CrossRef]

13. Murtaza, M.A.; Pandya, A.J.; Khan, M.M.H. Buffalo Milk Utilization for Dairy Products. In Handbook of Milk of Non-Bovine Mammals; Park, Y.W., Haenlein, G.F.W., Wendorff, W.L., Eds.; John Wiley \& Sons, Ltd.: Oxford, UK, 2017; pp. 284-342. ISBN 9781119110279.

14. Murtaza, M.A. Cheddar-type cheeses. In Reference Module in Food Science; Beddows, C., Ed.; Academic Press: Cambridge, MA, USA, 2016; pp. 1-8.

15. Hill, C.; Guarner, F.; Reid, G.; Gibson, G.R.; Merenstein, D.J.; Pot, B.; Morelli, L.; Canani, R.B.; Flint, H.J.; Salminen, S.; et al. Expert consensus document: The International Scientific Association for Probiotics and Prebiotics consensus statement on the scope and appropriate use of the term probiotic. Nat. Rev. Gastroenterol. Hepatol. 2014, 11, 506-514. [PubMed]

16. Siciliano, R.A.; Reale, A.; Mazzeo, M.F.; Morandi, S.; Silvetti, T.; Brasca, M. Paraprobiotics: A new perspective for functional foods and nutraceuticals. Nutrients 2021, 13, 1225. [CrossRef] [PubMed] 
17. Markowiak, P.; Ślizewska, K. Effects of probiotics, prebiotics, and synbiotics on human health. Nutrients 2017, 9, 1021. [CrossRef] [PubMed]

18. Rolim, F.R.L.; Neto, O.C.F.; Oliveira, M.E.G.; Oliveira, C.J.B.; Queiroga, R.C.R.E. Cheeses as food matrixes for probiotics: In vitro and in vivo tests. Trends Food Sci. Technol. 2020, 100, 138-154. [CrossRef]

19. Misra, S.S.; Sharma, A.; Bhattacharya, T.K.; Kumar, P.; Roy, S.S. Association of breed and polymorphism of $\alpha$-and $\alpha$-casein genes with milk quality and daily milk and constituent yield traits of buffaloes (Bubalus bubalis). Buffalo Bull. 2008, 27, $294-301$.

20. Akgun, A.; Yazici, F.; Gulec, H.A. Effect of reduced fat content on the physicochemical and microbiological properties of buffalo milk yoghurt. LWT-Food Sci. Technol. 2016, 74, 521-527. [CrossRef]

21. Barlowska, J.; Szwajkowska, M.; Litwińczuk, Z.; Król, J. Nutritional value and technological suitability of milk from various animal species used for dairy production. Compr. Rev. Food Sci. Food Saf. 2011, 10, 291-302. [CrossRef]

22. Islam, M.A.; Alam, M.K.; Islam, M.N.; Khan, M.A.S.; Ekeberg, D.; Rukke, E.O.; Vegarud, G.E. Principal milk components in buffalo, holstein cross, indigenous cattle and red chittagong cattle from Bangladesh. Asian-Australas. J. Anim. Sci. 2014, 27, 886-897.

23. Dimitrov, T.; Mihaylova, G.; Boycheva, S.; Naydenova, N.; Tsankova, M. Changes in the amino acid composition of buffalo milk after chemical activation of its lactoperoxidase system. Ital. J. Anim. Sci. 2007, 6, 1050-1052.

24. Khan, B.B.; Iqbal, A. The water buffalo: An underutilized source of milk and meat-A review. Pakistan J. Zool. Supple. 2009, 9 , 517-521.

25. Talpur, F.N.; Bhanger, M.I.; Khooharo, A.A.; Memon, G.Z. Seasonal variation in fatty acid composition of milk from ruminants reared under the traditional feeding system of Sindh, Pakistan. Livest. Sci. 2008, 118, 166-172.

26. Patiño, E.M.; Pochon, D.O.; Faisal, E.L.; Cedrés, J.F.; Mendez, F.I.; Stefani, C.G.; Crudeli, G. Influence of breed, year season and lactation stage on the buffalo milk mineral content. Ital. J. Anim. Sci. 2007, 6, 1046-1049. [CrossRef]

27. Giacinti, G.; Basiricò, L.; Ronchi, B.; Bernabucci, U. Lactoferrin concentration in buffalo milk. Ital. J. Anim. Sci. 2013, 12, 139-143. [CrossRef]

28. Di Luccia, A.; Picariello, G.; Trani, A.; Alviti, G.; Loizzo, P.; Faccia, M.; Addeo, F. Occurrence of $\beta$-casein fragments in cold-stored and curdled river buffalo (Bubalus bubalis L.) milk. J. Dairy Sci. 2009, 92, 1319-1329. [CrossRef]

29. Moio, L.; Langlois, D.; Etievant, P.; Addeo, F. Powerful Odorants in Bovine, Ovine, Caprine and Water Buffalo Milk Determined by Means of Gas Chromatography-Olfactometry. J. Dairy Res. 1993, 60, 215-222. [CrossRef]

30. Metchnikoff, E. The Prolongation of Life; G. P. Putnams's Sons: New York, NY, USA, 1907.

31. Reque, P.M.; Brandelli, A. Encapsulation of probiotics and nutraceuticals: Applications in functional food industry. Trends Food Sci. Technol. 2021, 114, 1-10. [CrossRef]

32. Ranadheera, C.S.; Vidanarachchi, J.K.; Rocha, R.S.; Cruz, A.G.; Ajlouni, S. Probiotic delivery through fermentation: Dairy vs. non-dairy beverages. Fermentation 2017, 3, 67. [CrossRef]

33. Vergin, F. Anti-und Probiotika. Hippokrates 1954, 25, 116-119.

34. FAO; WHO. Guidelines for the Evaluation of Probiotics in Food; FAO: Rome, Italy; WHO: Geneva, Switzerland, 2002.

35. Figueroa-González, I.; Quijano, G.; Ramírez, G.; Cruz-Guerrero, A. Probiotics and prebiotics-perspectives and challenges. J. Sci. Food Agric. 2011, 91, 1341-1348. [CrossRef]

36. Simões da Silva, T.M.; Piazentin, A.C.M.; Mendonça, C.M.N.; Converti, A.; Bogsan, C.S.B.; Mora, D.; de Souza Oliveira, R.P. Buffalo milk increases viability and resistance of probiotic bacteria in dairy beverages under in vitro simulated gastrointestinal conditions. J. Dairy Sci. 2020, 103, 7890-7897. [CrossRef] [PubMed]

37. Saarela, M.; Virkajärvi, I.; Alakomi, H.L.; Sigvart-Mattila, P.; Mättö, J. Stability and functionality of freeze-dried probiotic Bifidobacterium cells during storage in juice and milk. Int. Dairy J. 2006, 16, 1477-1482. [CrossRef]

38. Ricci, A.; Allende, A.; Bolton, D.; Chemaly, M.; Davies, R.; Girones, R.; Herman, L.; Koutsoumanis, K.; Lindqvist, R.; Nørrung, B.; et al. Scientific opinion on the update of the list of QPS-recommended biological agents intentionally added to food or feed as notified to EFSA. EFSA J. 2017, 15, e04664.

39. European Commission. On a Generic Approach to the Safety Assessment of Micro-Organisms Used in Feed/Food and Feed/Food Production; European Commission: Brussels, Belgium, 2003.

40. EFSA Qualified Presumption of Safety (QPS). Available online: https://www.efsa.europa.eu/en/topics/topic/qualifiedpresumption-safety-qps (accessed on 23 July 2021).

41. Bis-Souza, C.V.; Pateiro, M.; Domínguez, R.; Penna, A.L.B.; Lorenzo, J.M.; Silva Barretto, A.C. Impact of fructooligosaccharides and probiotic strains on the quality parameters of low-fat Spanish Salchichón. Meat Sci. 2020, 159, 107936.

42. Siró, I.; Kápolna, E.; Kápolna, B.; Lugasi, A. Functional food. Product development, marketing and consumer acceptance-A review. Appetite 2008, 51, 456-467. [CrossRef] [PubMed]

43. European Food Safety Authority (EFSA). Opinion of the Scientific Committee on a request from EFSA related to a generic approach to the safety assessment by EFSA of microorganisms used in food/feed and the production of food/feed additives. EFSA J. 2005, 3, 1-12.

44. Oelschlaeger, T.A. Mechanisms of probiotic actions-A review. Int. J. Med. Microbiol. 2010, 300, 57-62. [CrossRef]

45. Pineiro, M.; Asp, N.G.; Reid, G.; Macfarlane, S.; Morelli, L.; Brunser, O.; Tuohy, K. FAO Technical meeting on prebiotics. J. Clin. Gastroenterol. 2008, 42 (Suppl. 3), S156-S159. [CrossRef] 
46. Suganya, K.; Koo, B.-S. Gut-Brain Axis: Role of Gut Microbiota on Neurological Disorders and How Probiotics/Prebiotics Beneficially Modulate Microbial and Immune Pathways to Improve Brain Functions. Int. J. Mol. Sci. 2020, 21, 7551. [CrossRef]

47. Zheng, J.; Wittouck, S.; Salvetti, E.; Franz, C.M.A.P.; Harris, H.M.B.; Mattarelli, P.; O'Toole, P.W.; Pot, B.; Vandamme, P.; Walter, J.; et al. A taxonomic note on the genus Lactobacillus: Description of 23 novel genera, emended description of the genus Lactobacillus Beijerinck 1901, and union of Lactobacillaceae and Leuconostocaceae. Int. J. Syst. Evol. Microbiol. 2020, 70, 2782-2858. [CrossRef]

48. Li, P.; Gu, Q. Complete genome sequence of Lactobacillus plantarum LZ95, a potential probiotic strain producing bacteriocins and B-group vitamin riboflavin. J. Biotechnol. 2016, 229, 1-2. [CrossRef]

49. Plaza-Diaz, J.; Ruiz-Ojeda, F.J.; Gil-Campos, M.; Gil, A. Mechanisms of action of probiotics. Adv. Nutr. 2019, 10, S49-S66. [PubMed]

50. Lee, B.H.; Lo, Y.H.; Pan, T.M. Anti-obesity activity of Lactobacillus fermented soy milk products. J. Funct. Foods $2013,5,905-913$.

51. Lee, A.; Lee, Y.J.; Yoo, H.J.; Kim, M.; Chang, Y.; Lee, D.S.; Lee, J.H. Consumption of dairy yogurt containing Lactobacillus paracasei ssp. paracasei, Bifidobacterium animalis ssp. lactis and Heat-Treated Lactobacillus plantarum improves immune function including natural killer cell activity. Nutrients 2017, 9, 558

52. Vargas-Ramella, M.; Pateiro, M.; Gavahian, M.; Franco, D.; Zhang, W.; Khaneghah, A.M.; Guerrero-Sánchez, Y.; Lorenzo, J.M. Impact of pulsed light processing technology on phenolic compounds of fruits and vegetables. Trends Food Sci. Technol. 2021, 115, $1-11$.

53. Omar, J.M.; Chan, Y.M.; Jones, M.L.; Prakash, S.; Jones, P.J.H. Lactobacillus fermentum and Lactobacillus amylovorus as probiotics alter body adiposity and gut microflora in healthy persons. J. Funct. Foods 2013, 5, 116-123. [CrossRef]

54. Shiby, V.K.; Mishra, H.N. Fermented milks and milk products as functional foods-A review. Crit. Rev. Food Sci. Nutr. 2013, 53, 482-496.

55. Chen, M.J.; Tang, H.Y.; Chiang, M.L. Effects of heat, cold, acid and bile salt adaptations on the stress tolerance and protein expression of kefir-isolated probiotic Lactobacillus kefiranofaciens M1. Food Microbiol. 2017, 66, 20-27. [CrossRef] [PubMed]

56. Farag, M.A.; Jomaa, S.A.; El-wahed, A.A.; El-seedi, H.R. The many faces of kefir fermented dairy products: Quality characteristics, flavour chemistry, nutritional value, health benefits, and safety. Nutrients 2020, 12, 346. [CrossRef] [PubMed]

57. Iyer, R.; Tomar, S.K.; Uma Maheswari, T.; Singh, R. Streptococcus thermophilus strains: Multifunctional lactic acid bacteria. Int. Dairy J. 2010, 20, 133-141.

58. De Vuyst, L.; Tsakalidou, E. Streptococcus macedonicus, a multi-functional and promising species for dairy fermentations. Int. Dairy J. 2008, 18, 476-485. [CrossRef]

59. Beltrán-Barrientos, L.M.; González-Córdova, A.F.; Hernández-Mendoza, A.; Torres-Inguanzo, E.H.; Astiazarán-García, H.; Esparza-Romero, J.; Vallejo-Cordoba, B. Randomized double-blind controlled clinical trial of the blood pressure-lowering effect of fermented milk with Lactococcus lactis: A pilot study. J. Dairy Sci. 2018, 101, 2819-2825. [CrossRef]

60. Sabir, F.; Beyatli, Y.; Cokmus, C.; Onal-Darilmaz, D. Assessment of potential probiotic properties of Lactobacillus spp., Lactococcus spp., and Pediococcus spp. strains isolated from Kefir. J. Food Sci. 2010, 75, M568-M573. [CrossRef] [PubMed]

61. Soleymanzadeh, N.; Mirdamadi, S.; Mirzaei, M.; Kianirad, M. Novel $\beta$-casein derived antioxidant and ACE-inhibitory active peptide from camel milk fermented by Leuconostoc lactis PTCC1899: Identification and molecular docking. Int. Dairy J. 2019, 97, 201-208. [CrossRef]

62. Soleymanzadeh, N.; Mirdamadi, S.; Kianirad, M. Antioxidant activity of camel and bovine milk fermented by lactic acid bacteria isolated from traditional fermented camel milk (Chal). Dairy Sci. Technol. 2016, 96, 443-457. [CrossRef]

63. Morales, P.; Fernández-García, E.; Nuñez, M. Production of volatile compounds in cheese by Pseudomonas fragi strains of dairy origin. J. Food Prot. 2005, 68, 1399-1407. [CrossRef]

64. Stanborough, T.; Fegan, N.; Powell, S.M.; Singh, T.; Tamplin, M.; Chandry, P.S. Genomic and metabolic characterization of spoilage-associated Pseudomonas species. Int. J. Food Microbiol. 2018, 268, 61-72. [CrossRef] [PubMed]

65. Zhang, D.; Palmer, J.; Teh, K.H.; Calinisan, M.M.A.; Flint, S. Milk fat influences proteolytic enzyme activity of dairy Pseudomonas species. Int. J. Food Microbiol. 2020, 320, 108543. [CrossRef]

66. Sakandar, H.A.; Zhang, H. Trends in Probiotic(s)-Fermented milks and their in vivo functionality: A review. Trends Food Sci. Technol. 2021, 110, 55-65. [CrossRef]

67. EFSA-BIOHAZ Panel The 2019 updated list of QPS status recommended biological agents in support of EFSA risk assessments. EFSA J. 2021, 17, 1-5.

68. Marino, M.; Dubsky de Wittenau, G.; Saccà, E.; Cattonaro, F.; Spadotto, A.; Innocente, N.; Radovic, S.; Piasentier, E.; Marroni, F. Metagenomic profiles of different types of Italian high-moisture Mozzarella cheese. Food Microbiol. 2019, 79, 123-131. [CrossRef] [PubMed]

69. Nguyen, H.T.H.; Ong, L.; Lefèvre, C.; Kentish, S.E.; Gras, S.L. The microstructure and physicochemical properties of probiotic buffalo yoghurt during fermentation and storage: A comparison with bovine yoghurt. Food Bioprocess Technol. 2014, 7, 937-953.

70. Tan, W.S.; Budinich, M.F.; Ward, R.; Broadbent, J.R.; Steele, J.L. Optimal growth of Lactobacillus casei in a Cheddar cheese ripening model system requires exogenous fatty acids. J. Dairy Sci. 2012, 95, 1680-1689. [CrossRef] [PubMed]

71. Gul, O.; Mortas, M.; Atalar, I.; Dervisoglu, M.; Kahyaoglu, T. Manufacture and characterization of kefir made from cow and buffalo milk, using kefir grain and starter culture. J. Dairy Sci. 2015, 98, 1517-1525. [PubMed] 
72. Leite, A.M.d.O.; Miguel, M.A.L.; Peixoto, R.S.; Rosado, A.S.; Silva, J.T.; Paschoalin, V.M.F. Microbiological, technological and therapeutic properties of kefir: A natural probiotic beverage. Brazilian J. Microbiol. 2013, 44, 341-349. [CrossRef]

73. Ménard, O.; Ahmad, S.; Rousseau, F.; Briard-Bion, V.; Gaucheron, F.; Lopez, C. Buffalo vs. cow milk fat globules: Size distribution, zeta-potential, compositions in total fatty acids and in polar lipids from the milk fat globule membrane. Food Chem. 2010, 120, 544-551.

74. FAO. Buffalo Production and Research; FAO: Rome, Italy, 2007.

75. Ahmad, S.; Anjum, F.M.; Huma, N.; Sameen, A.; Zahoor, T. Composition and physico-chemical characteristics of buffalo milk with particular emphasis on lipids, proteins, minerals, enzymes and vitamins. J. Anim. Plant Sci. 2013, $23,62-74$.

76. Erkaya, T.; Ürkek, B.; Doğru, Ü.; Çetin, B.; Şengül, M. Probiotic butter: Stability, free fatty acid composition and some quality parameters during refrigerated storage. Int. Dairy J. 2015, 49, 102-110. [CrossRef]

77. Gao, J.; Li, X.; Zhang, G.; Sadiq, F.A.; Simal-Gandara, J.; Xiao, J.; Sang, Y. Probiotics in the dairy industry-Advances and opportunities. Compr. Rev. Food Sci. Food Saf. 2021, 3937-3982. [CrossRef]

78. Liu, Y.; Tran, D.Q.; Rhoads, J.M. Probiotics in disease prevention and treatment. J. Clin. Pharmacol. 2018, 58, S164-S179.

79. Barreto, F.M.; Colado Simão, A.N.; Morimoto, H.K.; Batisti Lozovoy, M.A.; Dichi, I.; Miglioranza, L.H.d.S. Beneficial effects of Lactobacillus plantarum on glycemia and homocysteine levels in postmenopausal women with metabolic syndrome. Nutrition 2014, 30, 939-942. [CrossRef]

80. Hariri, M.; Salehi, R.; Feizi, A.; Mirlohi, M.; Ghiasvand, R.; Habibi, N. A randomized, double-blind, placebo-controlled, clinical trial on probiotic soy milk and soy milk: Effects on epigenetics and oxidative stress in patients with type II diabetes. Genes Nutr. 2015, 10, 1-8. [CrossRef] [PubMed]

81. Hertzler, S.R.; Clancy, S.M. Kefir improves lactose digestion and tolerance in adults with lactose maldigestion. J. Am. Diet. Assoc. 2003, 103, 582-587.

82. Liu, Z.; Qin, H.; Yang, Z.; Xia, Y.; Liu, W.; Yang, J.; Jiang, Y.; Zhang, H.; Yang, Z.; Wang, Y.; et al. Randomised clinical trial: The effects of perioperative probiotic treatment on barrier function and post-operative infectious complications in colorectal cancer surgery - A double-blind study. Aliment. Pharmacol. Ther. 2011, 33, 50-63. [CrossRef] [PubMed]

83. Nobaek, S.; Johansson, M.-L.; Molin, G.; Ahrné, S.; Jeppsson, B. Alteration of intestinal microflora is associated with reduction in abdominal bloating and pain in patients with irritable bowel syndrome. Am. J. Gastroenterol. 2000, 95, 1231-1238. [CrossRef]

84. Sharafedtinov, K.K.; Plotnikova, O.A.; Alexeeva, R.I.; Sentsova, T.B.; Songisepp, E.; Stsepetova, J.; Smidt, I.; Mikelsaar, M. Hypocaloric diet supplemented with probiotic cheese improves body mass index and blood pressure indices of obese hypertensive patients - A randomized double-blind placebo-controlled pilot study. Nutr. J. 2013, 12, 1-11. [CrossRef]

85. Rajkumar, H.; Mahmood, N.; Kumar, M.; Varikuti, S.R.; Challa, H.R.; Myakala, S.P. Effect of probiotic (VSL\#3) and omega-3 on lipid profile, insulin sensitivity, inflammatory markers, and gut colonization in overweight adults: A randomized, controlled trial. Mediators Inflamm. 2014, 2014, 348959.

86. Bhathena, J.; Martoni, C.; Kulamarva, A.; Urbanska, A.M.; Malhotra, M.; Prakash, S. Orally delivered microencapsulated live probiotic formulation lowers serum lipids in hypercholesterolemic hamsters. J. Med. Food 2009, 12, 310-319. [CrossRef] [PubMed]

87. Weston, S.; Halbert, A.; Richmond, P.; Prescott, S.L. Effects of probiotics on atopic dermatitis: A randomised controlled trial. Arch. Dis. Child. 2005, 90, 892-897. [CrossRef] [PubMed]

88. Chen, Y.P.; Hsiao, P.J.; Hong, W.S.; Dai, T.Y.; Chen, M.J. Lactobacillus kefiranofaciens M1 isolated from milk kefir grains ameliorates experimental colitis in vitro and in vivo. J. Dairy Sci. 2012, 95, 63-74. [CrossRef] [PubMed]

89. Chen, Y.P.; Lee, T.Y.; Hong, W.S.; Hsieh, H.H.; Chen, M.J. Effects of Lactobacillus kefiranofaciens M1 isolated from kefir grains on enterohemorrhagic Escherichia coli infection using mouse and intestinal cell models. J. Dairy Sci. 2013, 96, 7467-7477. [CrossRef]

90. Hong, W.S.; Chen, Y.P.; Chen, M.J. The antiallergic effect of kefir lactobacilli. J. Food Sci. 2010, 75, H244-H253. [CrossRef] [PubMed]

91. Niers, L.; Martín, R.; Rijkers, G.; Sengers, F.; Timmerman, H.; Van Uden, N.; Smidt, H.; Kimpen, J.; Hoekstra, M. The effects of selected probiotic strains on the development of eczema (the PandA study). Allergy Eur. J. Allergy Clin. Immunol. 2009, 64, 1349-1358. [CrossRef] [PubMed]

92. Agerholm-Larsen, L.; Raben, A.; Haulrik, N.; Hansen, A.S.; Manders, M.; Astrup, A. Effect of 8 week intake of probiotic milk products on risk factors for cardiovascular diseases. Eur. J. Clin. Nutr. 2000, 54, 288-297. [CrossRef] [PubMed]

93. Alisi, A.; Bedogni, G.; Baviera, G.; Giorgio, V.; Porro, E.; Paris, C.; Giammaria, P.; Reali, L.; Anania, F.; Nobili, V. Randomised clinical trial: The beneficial effects of VSL\#3 in obese children with non-alcoholic steatohepatitis. Aliment. Pharmacol. Ther. 2014, 39, 1276-1285. [PubMed]

94. Aller, R.; De Luis, D.A.; Izaola, O.; Conde, R.; Gonzalez Sagrado, M.; Primo, D.; De La Fuente, B.; Gonzalez, J. Effect of a probiotic on liver aminotransferases in nonalcoholic fatty liver disease patients: A double blind randomized clinical trial. Eur. Rev. Med. Pharmacol. Sci. 2011, 15, 1090-1095. [PubMed]

95. D’Onofrio, N.; Cacciola, N.A.; Martino, E.; Borrelli, F.; Fiorino, F.; Lombardi, A.; Neglia, G.; Balestrieri, M.L.; Campanile, G. ROS-mediated apoptotic cell death of human colon cancer LoVo cells by milk $\delta$-calerobetaine. Sci. Rep. 2020, 10, 1-15. [CrossRef] 